\section{LEEDS, 1967}

\section{Sir Willis Jackson}

Sir Willis Jackson, who will be President of the British Association in 1966-67, and who will deliver the Presidential Address at Leeds in 1967, has been an elder statesman for as long as most people can remember, but he is a mere 62 years old. He was born in Burnley and educated there and at tho University of Manchester. His first job was as a lecturer in electrical engineering in the then College of Technology at Manchester, from where he moved to Oxford in the early thirties. He went into industry, with Metropolitan Vickers Electrical Co., for a brief spell before the Second World War and then became professor of what was called elcetrotechnics at the University of Manchester and professor of electrical engineering at the Imperial College of Science and Technology. His public reputation was enormously enhanced by his spell as Director of Research and Education at Associated Electrical Industries (Manchester), Ltd., in the fifties. There Sir Willis was responsible for building up an efficient and imaginative scheme for the training of people at all levels, especially young apprentices. The success of the training scheme was such that it became a model followed widely by other similarly placed companies in British industry. Sir Willis left industry to become head of the Department of Electrical Engineoring at Imperial College in 1961.

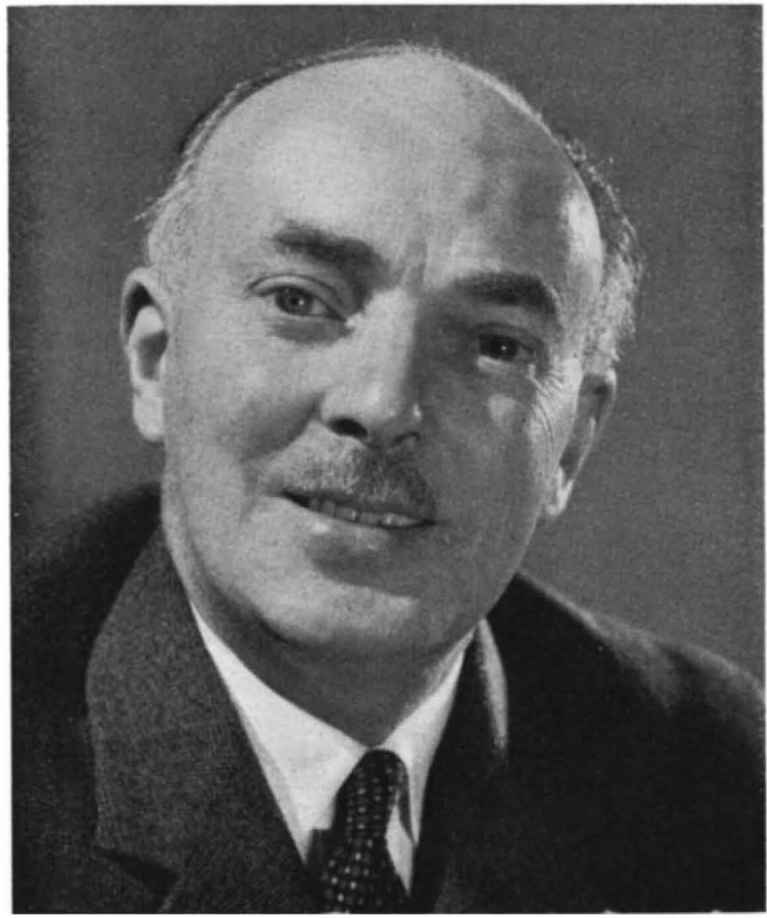

For the past decade Sir Willis has also been extromely active as a member of committecs concerned with public policy towards science and technology. He joined the Advisory Council on Scientific Policy in 1961 and has remained the chairman of the sub-committee responsible for scientific manpower since he took over from Sir Solly Zuckerman in 1963. The sub-committee has recently been preparing an up-to-date survey of the use made of scientific manpower in Britain which is due to be published in September 1966. The chances are that this document will have an important bearing on the discussions now going on about the spending of public moncy on science on one hand and technology on the other.

The election of Sir Willis Jackson as President for 1967 will do much to gratify the wish of the British Association to be more intimately concerned with technology.

\section{DUNDEE, 1968}

\section{Dame Kathleen Lonsdale}

Scientists throughout the United Kingdom, whether suffragettes or not, will be delighted to learn that Professor Dame Kathleen Lonsdale has been elected President of the British Association for the Advancement of Science for 1968. Professor Lonsdale was one of the first two women to be elected to the Royal Society of London; she now bocomes the first woman to hold the presidency of the British Association-an election long overdue.

A pioneer in the field of X-ray crystallography, Professor Lonsdale worked with Sir William Bragg's original team in the early $1920 \mathrm{~s}$. Since then her work has encroached on the structure of the benzene ring, magnetic anisotropy of crystals and molecules, X-ray scattering in diamonds and ice, and diamond/graphite transitions; more recently it has been applied to medical fiolds in which she is investigating bladder stones and other calculi.

Throughout her views on various aspects of life, science and politics there runs a strong ethical thread. Professor Lonsdale is known as a Quaker and a pacifist. She is forthright in hor views, and her refusal to register for wartime duties led to a prison sentence in 1943 .

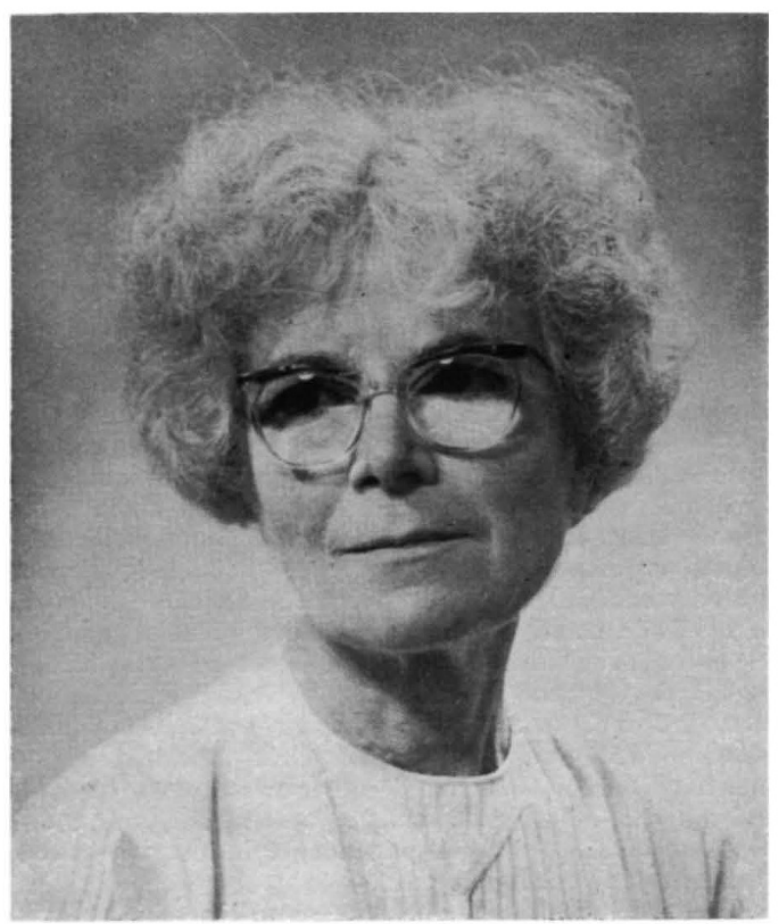

She is known to hold strong views as to the moral obligations of the scientists. As citizens she believes they ought to be vigilant to see that the applications of science which case their own conditions of life do not lead to unnecessary danger for other people. She has also said that they have a duty towards the general public and towards the statesmen and politicians to make sure that they are well informed-here perhaps lies the reason for her constant support of the activities of the British Association over many years.

Professor Lonsdale is an inspiration to all who work with her in the Department of Chemistry at University College, London, or come into contact with her through her extonsive committee work with the International Union of Crystallography, the Royal Institution, and various prison and borstal institutions.

Married to Dr. T. J. Lonsdale, a scientist now retired but previously at the Road Research Laboratory, Professor Lonsdalo has two daughters, one son, six grandsons and two granddaughters. 